\title{
Role of G2-S16 Polyanionic Carbosilane Dendrimer in the Prevention of Respiratory Syncytial Virus Infection In Vitro and In Vivo in Mice
}

\author{
Ignacio Rodriguez-Izquierdo ${ }^{1,2}$, Rafael Ceña-Diez ${ }^{1}$, Maria Jesús Serramia ${ }^{1,2}$, Rosa Rodriguez-Fernández ${ }^{3} \mathbb{D}$, \\ Isidoro Martínez ${ }^{4}$ (D) and Mariángeles Muñoz-Fernández ${ }^{1,2, *(\mathbb{D})}$
}

\section{check for}

updates

Citation: Rodriguez-Izquierdo, I.; Ceña-Diez, R.; Serramia, M.J.;

Rodriguez-Fernández, R.; Martínez, I.; Muñoz-Fernández, M. Role of G2-S16 Polyanionic Carbosilane Dendrimer in the Prevention of Respiratory Syncytial Virus Infection In Vitro and In Vivo in Mice. Polymers 2021, 13, 2141. https://doi.org/10.3390/ polym13132141

Academic Editor: Diego Antonioli

Received: 9 June 2021

Accepted: 25 June 2021

Published: 29 June 2021

Publisher's Note: MDPI stays neutral with regard to jurisdictional claims in published maps and institutional affiliations.

Copyright: (c) 2021 by the authors. Licensee MDPI, Basel, Switzerland. This article is an open access article distributed under the terms and conditions of the Creative Commons Attribution (CC BY) license (https:// creativecommons.org/licenses/by/ $4.0 /)$
1 Immunology Section, Head Inmuno-Biology Molecular Laboratory, Gregorio Marañón University General Hospital (HGUGM), Gregorio Marañón Health Research Institute (IiSGM), 28007 Madrid, Spain; igna.iri.93@gmail.com (I.R.-I.); rcena48@gmail.com (R.C.-D.); mjserramia.hgugm@salud.madrid.org (M.J.S.) 2 Spanish HIV HGM BioBank, C/Dr. Esquerdo 46, 28007 Madrid, Spain

3 Hospital de Pediatría, Gregorio Marañón University General Hospital (HGUGM), Gregorio Marañón Health Research Institute (IiSGM), C/Dr. Esquerdo 46, 28007 Madrid, Spain; rrfernandez@salud.madrid.org

4 Unidad de Infección Viral e Inmunidad, Centro Nacional de Microbiología, Instituto de Salud Carlos III, Majadahonda, 28007 Madrid, Spain; imago@isciii.es

* Correspondence: mmunoz.hgugm@gmail.com or mmunoz.hgugm@salud.madrid.org; Tel.: +34-91-462-4684

Abstract: The respiratory syncytial virus (RSV) causes respiratory infection and bronchiolitis, requiring hospitalization mainly in infants. The interaction between RSV, envelope glycoproteins $G$ and F, and cell surface heparan sulfate proteoglycans (HSPG) is required for binding and entry into the host cells. A G2-S16 polyanionic carbosilane dendrimer was identified as a possible RSV inhibitor. We speculated that the G2-S16 dendrimer adheres to the host cell-surface HSPG, acts through binding to HS receptors, and prevents further RSV infection. The G2-S16 dendrimer was non-toxic when applied intranasally to Balb/c mice, and interestingly enough, this G2-S16 dendrimer inhibits 85\% RSV. Therefore, our G2-S16 dendrimer could be a candidate for developing a new possible therapy against RSV infection.

Keywords: RSV infection; G2-S16 dendrimer; syncytium; nanotechnology

\section{Introduction}

Nanotechnology plays an important role in the treatment of broad viral infections. Particularly, polyanionic carbosilane dendrimers, a class of hyper-branched polymers with a nanoscale globular shape, well-defined functional groups at periphery, hydrophobic, or hydrophilic cavities in the interior, and low polydispersity have proven to be broadspectrum antivirals with promising results. Globally, RSV infection is estimated at 64 million cases and 160,000 deaths annually [1]. Current advances in the use of nanoparticle technology such as dendrimers have found new opportunities that address some limitations in effective therapeutic agents. This RSV represents an important health problem in newborns, infants, young children, immunocompromised patients, and the elderly, due to the fact that there is no licensed vaccine for RSV and an effective therapeutic agent is needed [2-4]. RSV is the main cause of mortality and morbidity in infants until 2 years old [5].

An early RSV infection treatment is mandatory to avoid lung tissue damage, the potential development of reactive airway disorders, and complications from sustained oxygen deprivation. Although different vaccines are being studied for respiratory viruses [6] nanotechnology and different nanosystems such as gold nanomaterials have shown low toxicity and a wide range of biomedical applications, such as effective therapies [7]. Gold nanorods are being investigated as new possible treatments of RSV and for various biomedical applications [8]. Metallic nanoparticles show antiviral activity against respiratory 
viruses [9]. Another study made with nanoparticles against RSV was shown to have very promising data as prophylactic or therapeutic approaches, placing nanoparticles as a very interesting and effective tool; meanwhile, the vaccine is developed [10]. Additionally, mice models had improved the present airway epithelial cells culture as well as the data obtained and mimic real respiratory infections [5,11,12].

The first infection step is mediated by the interactions of RSV envelope glycoproteins $\mathrm{G}$ and $\mathrm{F}$ and the cell surface HSPG [13-20]. Indeed, to generate a compound capable of blocking the interaction between heparan sulfate (HS) and HBD, resulting in an inhibition of infection generated by different viruses, such as RSV, would be an interesting therapeutic approach. This scenario makes the G2-S16 dendrimer an important tool for antiviral research, and the dendrimers could be a new possible effective therapeutic agent against RSV. Our main objective has been to evaluate the G2-S16 dendrimer for its possible antiRSV activity and not only to research its mechanisms of action but also its biocompatibility in human cells lines and in BALB/c mice.

\section{Materials and Methods}

\subsection{Dendrimers and Reagents}

G2-S16 dendrimer $\left(\mathrm{C}_{112} \mathrm{H}_{244} \mathrm{~N}_{8} \mathrm{Na}_{16} \mathrm{O}_{48} \mathrm{~S}_{16} \mathrm{Si}_{13} ; \mathrm{Mw}: 3717.15 \mathrm{~g} / \mathrm{mol}\right)$ and G2-S16FITC dendrimer labeled $\left(\mathrm{C}_{129} \mathrm{H}_{249} \mathrm{~N}_{9} \mathrm{Na}_{14} \mathrm{O}_{47} \mathrm{~S}_{15} \mathrm{Si}_{13} ; 3946.29 \mathrm{~g} / \mathrm{mol}\right)$ were synthesized and characterized as previously described [21-23] (Figure 1A). Both dendrimers were dissolved in distillated water, and dilution to $\mu \mathrm{M}$ range was generated in distillated water from stock.

A
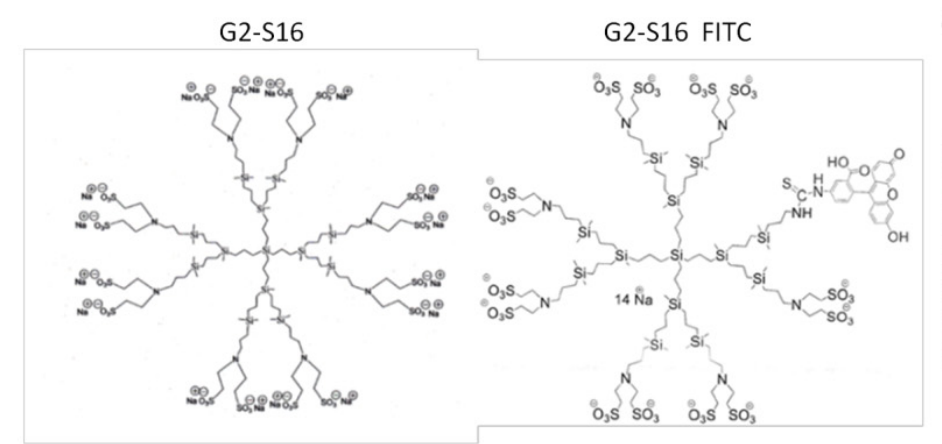

C

HEp-2

B

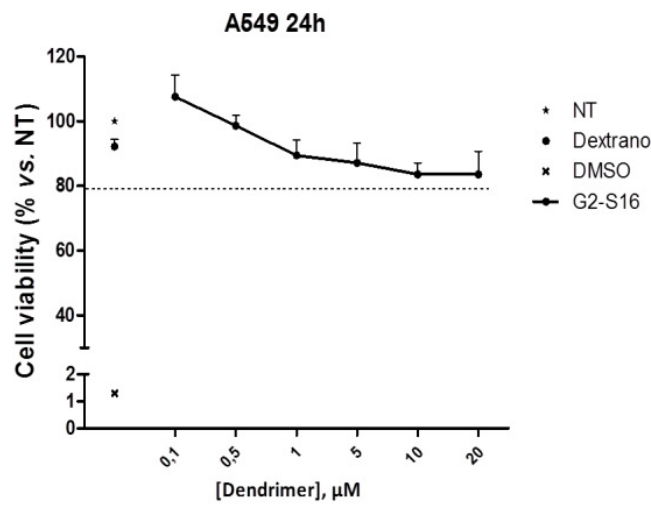

D

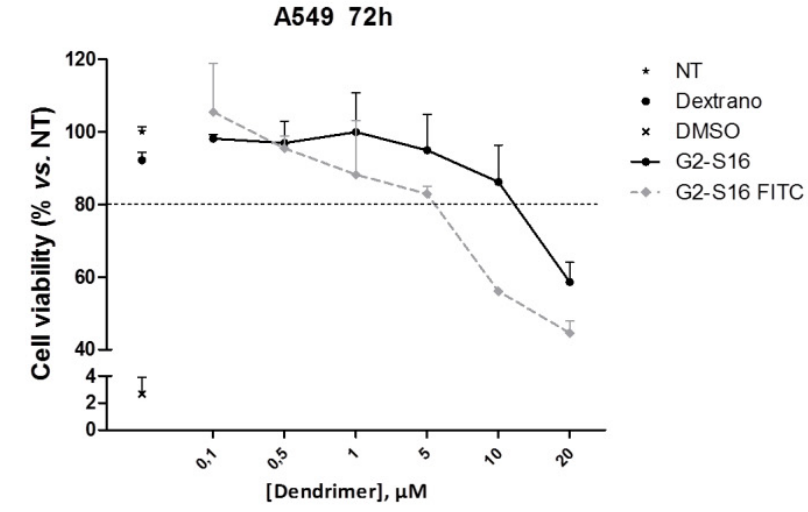

Figure 1. (A) Schematic representation of G2-S16 and G2-S16-FITC dendrimers. (B-D) Viability of A549 cells was evaluated by MTT assay after $24 \mathrm{~h}(\mathbf{B}), 72 \mathrm{~h}(\mathrm{D})$, or 5 days of exposure (C) in HEp-2 cells to a range of G2-S16 dendrimer concentrations; $80 \%$ of viability was set as the limit of toxicity for the G2-S16 dendrimer. Dextran $20 \mu \mathrm{M}$ and DMSO $10 \%$ were used as controls. Data were represented as mean \pm standard deviation of three independent experiments by triplicate. $\mathrm{NT}=$ non-treated control; DXT = dextran; DMSO = dimethyl sulfoxide. 


\subsection{Cells and Viruses}

The A549 human epithelial cell line (ATCC CCL-185, Manassas, VA, USA) and HEp-2 human epithelial cell line (ATCC CCL-23, Manassas, VA, USA) were grown and maintained in Dulbecco's modified Eagle's medium (DMEM; Biochrom AG, Berlin, Germany) supplemented with $10 \%$ heat-inactivated fetal calf serum (FBS), a cocktail of antibiotics $(125 \mu \mathrm{g} / \mathrm{mL}$ ampicillin, $125 \mu \mathrm{g} / \mathrm{mL}$ cloxacillin, and $40 \mu \mathrm{g} / \mathrm{mL}$ gentamicin, Sigma, St Louis, $\mathrm{MO}, \mathrm{USA})$, and $1 \%$ L-glutamine in $5 \% \mathrm{CO}_{2}$ and $37^{\circ} \mathrm{C}$.

This RSV (long Strain, ATCC VR-26) was obtained from the American Type Culture Collection (ATCC, Manassas, VA, USA) and provided by Dr. Isidoro Martinez (Centro Nacional de Microbiologia, Instituto de Salud Carlos III). This RSV was propagated in HEp-2 cells as previously described [24,25] and G2-S16 dendrimer titers were determined by plaque assay in HEp-2 cells.

\subsection{Screening Procedure}

G2-S16 dendrimer toxicity was screened by MTT assay (Sigma, St Louis, MO, USA) according to manufacturer's instructions. A range of concentrations between 0.1 and $20 \mu \mathrm{M}$ were evaluated for this G2-S16 dendrimer. Dextran $10 \mu \mathrm{M}$ and DMSO $20 \mu \mathrm{M}$ (Honeywell, Charlotte, NC, USA) were used as control of cell viability and death, respectively, and $>80 \%$ cell viability was set as the minimum non-toxicity value. A549 or HEp-2 cells were treated with G2-S16 dendrimer ( 0.1 to $20 \mu \mathrm{M})$, for $24 \mathrm{~h}$ in the case of A549 cells or 5 days in the case of HEp-2 cells. MTT assay was added $(0.5 \mathrm{mg} / \mathrm{L})$, and generated crystals were dissolved in DMSO. After $2 \mathrm{~h}$, absorbance was read out in a Synergy 4 plate reader (BioTek, Winooski, VT, USA) at 570/690 nm.

\subsection{Inhibition Assay}

To determine the antiviral capacity of G2-S16 dendrimer against RSV, the maximum non-toxic concentration of the dendrimer was selected $(10 \mu \mathrm{M})$. RSV infection was performed on a monolayer of A549 cells in a 6-well plate. A549 cells $\left(5 \times 10^{5}\right)$ were plated and incubated for $24 \mathrm{~h}$, washed with fresh DMEM medium at $2 \%$ SFB, infected with RSV at 3 Multiplicity of Infection (MOI 3), and subsequently treated with G2-S16 dendrimer. After $1 \mathrm{~h}$ at $37^{\circ} \mathrm{C}$, the supernatant was removed, and the infection was left in $2 \mathrm{~mL}$ in fresh medium at $2 \%$ FBS for $24 \mathrm{~h}$ at $37^{\circ} \mathrm{C}$.

Viral titration was carried out on the HEp-2 cell line. HEp-2 cells were plated in a p6, and the titration of each of the conditions was carried out, infecting with $400 \mu \mathrm{L}$ of the viral supernatants generated in the A549 cells serially diluted $\left(10^{-1}, 10^{-2}\right.$ and $\left.10^{-3}\right)$ and the adsorption for $90 \mathrm{~min}$ at $37^{\circ} \mathrm{C}$. After infection with the supernatants, $3 \mathrm{~mL}$ of DMEM $2 \%$ SFB with $0.7 \%$ low melting point agarose (LMP) were added per well and kept at $4{ }^{\circ} \mathrm{C}$ for $30 \mathrm{~min}$ so that the agarose solidified. The infection was maintained for 5 days at $37^{\circ} \mathrm{C}$.

Plaques of lysis generated by RSV infection were revealed by immunostaining. Cells were firstly fixed in $4 \%$ formaldehyde for $45 \mathrm{~min}$ at room temperature (RT); after removing the semi-solid agarose medium, the monolayer was fixed with methanol for $5 \mathrm{~min}$ at RT. Cells were washed twice and incubated with PBS-SAB 1\% for $30 \mathrm{~min}$ at RT. Subsequently, the PBS-SAB was removed, and primary antibody (1:50 in 1\% PBS-SAB) was added for $1 \mathrm{~h}$ at RT. Secondary antibody (anti-mouse-peroxidase 1:500 in PBS-SAB 1\%) was added and incubated for $1 \mathrm{~h}$ at RT. The secondary antibody was removed, and plates were washed twice. Finally, the developing substrate was added ((citrate/phosphate $25 / 50 \mathrm{mM} \mathrm{pH}$ 5.0), $0.6 \mathrm{~mL}$ of 3-amino-9-ethylcarbazole (AEC) (Sigma, St Louis, MO, USA), $3.33 \mathrm{mg} / \mathrm{mL}$ in DMSO, and $20 \mu \mathrm{L} \mathrm{H}_{2} \mathrm{O}_{2}$ ) and after $20 \mathrm{~min}$, the substrate was removed and the plates were counted. The percentage of inhibition of each condition against RSV infection was determined by comparing with controls.

\subsection{Inhibitions of RSV Attachment to Host Cells}

The mechanism of action of G2-S16 dendrimer was determined based on the results obtained in the previous experiment, beginning to analyze the inhibition of RSV by means 
of the attachment mechanism, based on previously results obtained with G2-S16 dendrimer. A549 cells were plated on a p6 as described above. After $24 \mathrm{~h}$, the plate was pre-cooled at $4{ }^{\circ} \mathrm{C}$ for $30 \mathrm{~min}$. A549 cells were infected with RSV MOI 3 and simultaneously treated with previously selected concentration (G2-S16 $10 \mu \mathrm{M})$ for $1 \mathrm{~h}$ at $4{ }^{\circ} \mathrm{C}$. Subsequently, the cells were washed with fresh DMEM medium with $2 \%$ FBS and incubated for $24 \mathrm{~h}$ at $37^{\circ} \mathrm{C}$.

To titrate the RSV infection, HEp-2 cells were infected with the supernatants of the cultures obtained in the A549 cell line, according to the procedure described in the previous section, and 5 DPI, infection was revealed according to the protocol described above.

\subsection{G2-S16 Dendrimer-Cell Interaction Assay}

A549 cells were treated at maximum non-toxic concentrations of G2-S16 dendrimer for $2 \mathrm{~h}$ to test the capability of the G2-S16 dendrimer to interact with the cellular receptors, and it blocked the interaction of viral proteins with the host cell, inhibiting the infection. A549 cells were washed to remove G2-S16 dendrimer that did not bind to the cell surface, and MOI 3 RSV infection was performed. Then, $24 \mathrm{~h}$ post-infection, viral infection was revealed in HEp-2 cells as mentioned before.

\subsection{Binding of G2-S16 Dendrimer to RSV}

To test the percentage of inhibition due to the interaction between the G2-S16 dendrimer and RSV, viral particles were pre-incubated at a MOI 3 with G2-S16 dendrimer $1 \mathrm{~h}$ at $4{ }^{\circ} \mathrm{C}$. HEp-2 cells were plated in a 96-well plate in DMEM medium at $2 \%$ FBS and infected with the RSV-G2 inoculums for $1 \mathrm{~h}$ at $4{ }^{\circ} \mathrm{C}$. Cells were washed twice to remove unbound virus and fixed with $4 \%$ formaldehyde and blocked with 5\% SAB in PBS-Tween. Cell-bound virus was determined by incubating a primary antibody (1:50 in PBS-Tween) for $1 \mathrm{~h}$ at RT. Secondary antibody (anti-mouse-IgG peroxidase, 1:500 in PBS-Tween) was added after washing the plates twice, and it was incubated for $2 \mathrm{~h}$ at $37^{\circ} \mathrm{C}$. Then, the secondary antibody was removed, plates were washed, and ABTS developing substrate (2,2'-azino-bis- (3-ethylbenzothiazoline)-6-sulfonic acid)) (Thermo Scientific, Rock-ford, IL, USA) was added and incubated for $20 \mathrm{~min}$ at RT. The reaction was stopped with $1 \%$ sodium dodecyl sulfate (SDS) stop solution, and the absorbance at $405-410 \mathrm{~nm}$ was measured on a microplate reader BioTek Synergy ${ }^{\mathrm{TM}} 4$ Hybrid Microplate Reader (BioTek, Winooski, VT, USA).

\subsection{Syncytium Formation Assay}

The ability of G2-S16 dendrimer to block cell-to-cell RSV spread was analyzed. A549 cell viability was determined by MTT assay at $72 \mathrm{~h}$ post-exposure as mentioned above. For syncytium assay, A549 cells were infected with RSV at a MOI 10 and treated with a maximum non-toxic concentration of G2-S16 dendrimer or G2-S16-FITC dendrimer immediately after RSV adsorption. Then, $72 \mathrm{~h}$ later, A549 cells were stained for hematoxylin/eosin (H/E) or immune-stained. For H/E stain, A549 cells were washed with PBS and stained 10 min with hematoxylin and $10 \mathrm{~min}$ with eosin. Syncytium formation was evaluated under light microscopy.

Syncytium inhibition was evaluated by the immunostaining of A549 cells. Cells were infected and syncytium formation was determined by light microscopy. Once syncytia were visualized, A549 monolayer were fixed ( $3.7-4 \%$ PFA; $10 \mathrm{~min})$, permeabilized ( $0.1 \%$ Triton $\mathrm{X}-100 ; 5 \mathrm{~min}$ ), and incubated in PBS-BSA 5\% $30 \mathrm{~min}$. Monolayers were stained for RSV fusion protein (anti-human RSV, Sino Biological Inc, Beijing, China) and cellular receptor HSPG-2 (Sino Biological Inc, Beijing, China) (1:500 and 1:100 respectively). Phaloidin FITC conjugated (1:100) was used for actin filaments visualization. Secondary antibody antimouse IgG (Jackson InmunoResearch, Suffolk, UK) and anti-rabbit IgG (Thermo-Fisher Scientific, Waltham, MA, USA) were incubated for $1 \mathrm{~h}$, nuclei were stained with DAPI, and preparations were observed in a Zeiss LSM710 confocal microscope by using Zen 2015 software (Carl Zeiss Microimaging Inc., Thornwood, NY, USA). Syncytium inhibition was determined by counting number of syncytia in random files. 


\subsection{In Vivo Assays Statement}

$\mathrm{BALB} / \mathrm{c}$ mice studies were approved by the CBMSO Institutional Animal Care and Use Committee (CEEA-CBMSO, Madrid, Spain) and carried out following CEEA-CBMSO, National (Royal Decree 1201/2005), according to the Directive 2010/63/EU of the European Parliament guidelines and regulations. The ability of G2-S16 dendrimer to induce irritation and damage to BALB/c mice lung when administrated intranasally was studied. Twelve BALB/c mice (Charles River Laboratories, Wilmington, MA) (22 $\pm 2 \mathrm{~g}$ and 8 weeks old) were purchased. G2-S16 dendrimer treatment was applied intranasally in $\mathrm{BALB} / \mathrm{c}$ mice previously anesthetized with isoflurane (Forane, Abbott, Madrid, Spain). Therefore, BALB $/ \mathrm{c}$ mice were randomized into four groups. The BALB/c mice control group received $50 \mu \mathrm{L}$ of PBS intranasally. The BALB/c mice G2-S16 dendrimer group received $9.3 \mathrm{mg} / \mathrm{kg}$, $46.5 \mathrm{mg} / \mathrm{kg}$, or $93 \mathrm{mg} / \mathrm{kg}$ intranasally. Five days later, BALB/c mice were sacrificed, and lungs were extracted and conserved in 3.7-4\% PFA $w / v$ (PanReac AppliChem, Darmstadt, Germany).

The possible existence of inflammation, edema, alveolar congestion, bleeding, vascular thrombosis, and congestion in pulmonary parenchyma and/or inflammatory infiltrate, edema, bleeding, fibrosis, and neovascularization in pleura were evaluated in each sample. Values (score) assigned for each of these lesions were 0-4 (no changes-very serious injuries) as previously described [7].

Histological lesions in BALB/c mice lungs were evaluated with hematoxylin-eosin staining as previously described [7]. The existence of injury in pulmonary parenchyma and pleura was evaluated in each biological sample. These values were added, and the determined level of pulmonary damage was determined as minimum (1-6), average (7-10), moderate (10-14), or severe $(>14)$.

\subsection{In Vivo RSV Challenge Assay}

$\mathrm{BALB} / \mathrm{c}$ mice were randomized in the same four experimental groups as mentioned above. All mice were intranasally infected with $2.5 \times 10^{6} \mathrm{pfu}$ of RSV while anesthetized with isoflurane (Forane, Abbott, Madrid, Spain). G2-S16 dendrimer was applied intranasally 2 DPI in anesthetized mice. BALB/c mice were sacrificed 5 DPI, and lungs were extracted in order to extract RSV. The viral load of each lung was determined performing serial dilutions of $5 \mathrm{~mL}$ of grinded RSV infected lungs and titrated on HEp-2 cells as described.

\subsection{Statistical Analysis}

Statistical study was carried out with GraphPad Prism v7.0 software (GraphPad, San Diego, CA, USA) using a $t$-Test of unpaired values and a non-parametric test, including calculation of the mean, standard deviation, and $p$-values. The significance was solved at $p=0.05$. The data shown were analyzed from duplicate or triplicate in at least three independent experiments, unless in vivo assays, where the $n$ size and the pertinent analysis were determined in its corresponding section.

\section{Results}

\subsection{Biocompatibility of G2-S16 Polyanionic Carbosilane Dendrimer}

The biocompatibility of G2-S16 and G2-S16-FITC dendrimers (Figure 1A) in A549 cells at $24 \mathrm{~h}$ (Figure 1B) or $72 \mathrm{~h}$ (Figure 1D) and in HEp-2 cells at 5 days (Figure 1C) were evaluated by an MTT assay. The G2-S16 dendrimer concentration with viability $>80 \%$ in comparison with the control group was regarded as non-toxic. The G2-S16 dendrimer was not toxic at $10 \mu \mathrm{M}$. Biocompatibility at $72 \mathrm{~h}$ post-treatment in A549 cells showed that both G2-S16 and G2-S16-FITC dendrimers were non-toxic at $5 \mu \mathrm{M}$.

\subsection{G2-S16 Polyanionic Carbosilane Dendrimer against Respiratory Syncytial Virus}

We studied the G2-S16 dendrimer at maximum non-toxic concentrations for MTT assay. A549 cells were infected at an MOI 3 of RSV and treated at maximum non-toxic 
concentrations of G2-S16 dendrimer in Hep-2 cells. The G2-S16 dendrimer at $10 \mu \mathrm{M}$ inhibited RSV infection by $99-100 \%$ (Figure 2A). The G2-S16 dendrimer was active at non-toxic concentrations, and this G2-S16 dendrimer halts RSV infection ( $p$-value $<0.001$ vs. control) in A549 cells.

a
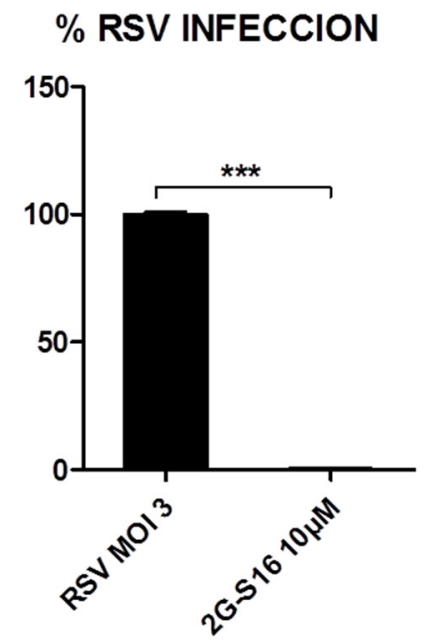

C

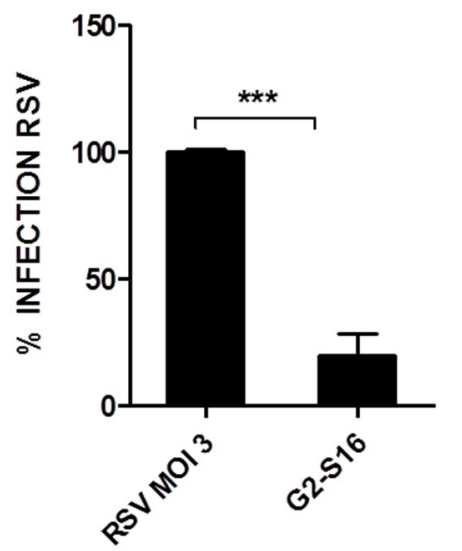

\section{b}

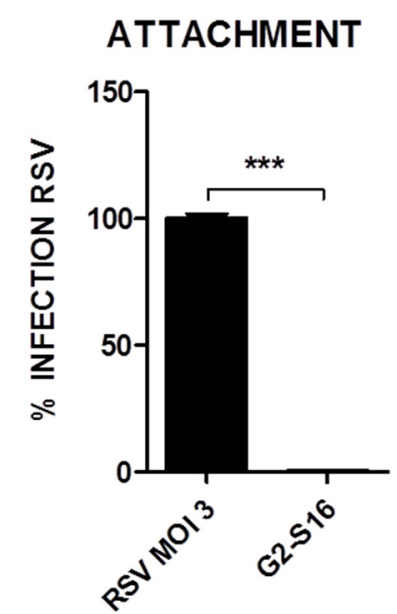

d RSV-PCD

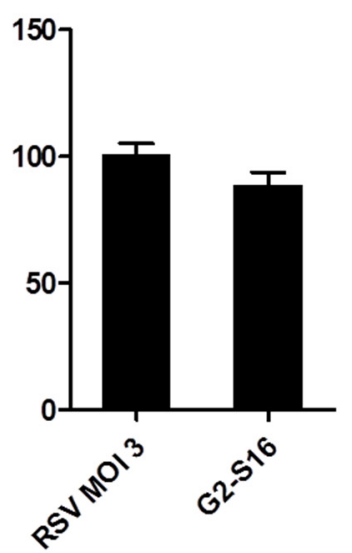

Figure 2. Mode of action of G2-S16 dendrimer against RSV infection. (a) Cells were infected $24 \mathrm{~h}$, and culture supernatants were titrated in HEp-2 cells. (b) The effect of G2-S16 dendrimer on RSV binding. A549 cells were pre-chilled at $4{ }^{\circ} \mathrm{C}$ for $30 \mathrm{~min}$ and then treated and infected with RSV for $1 \mathrm{~h}$ at $4{ }^{\circ} \mathrm{C}$. (c) Binding of G2-S16 dendrimer to cellular surface proteins. A549 cells were pre-treated $1 \mathrm{~h}$ with G2-S16 dendrimer. After incubation, A549 cells were washed to eliminate unbound G2-S16 dendrimer and infected with RSV. (d) Percentages of at one MOI 3 of RSV. The G2-S16 dendrimer was preincubated with RSV for $1 \mathrm{~h}$ at $4{ }^{\circ} \mathrm{C}$. HEp- 2 cells were infected $1 \mathrm{~h}$ at $3 \mathrm{MOI}$ at $4{ }^{\circ} \mathrm{C}$. The graph represents the relative mean of three independent experiments. G2-S16 dendrimer infection was made at a MOI 3. Infection control: non-treated infected A549 cells at 3 MOI. Data were represented as mean \pm standard deviation of three independent experiments. Error bars corresponding to the SD inter-experiment $(n=3),{ }^{* * *} p<0.001$.

\subsection{Mechanism of Action of G2-S16 Polyanionic Carbosilane Dendrimer}

The antiviral activity of G2-S16 dendrimer against RSV infection and the underlying mechanism of action was studied (Figure 2). We previously demonstrated that G2-S16 dendrimer inhibits RSV infection in a significant manner (99-100\%) (Figure 2A). We previously described that G2-S16 dendrimer inhibition against other viruses occurs in the early steps of the infection, acting in attachment events due to the interactions between peripheral groups and viral or host cells proteins or receptors [26,27]. In the case of RSV, the G2-S16 
dendrimer also inhibits the attachment of RSV with A549 cells (99-100\%; $p$-value $<0.0001)$ (Figure 2B). This inhibition could be due to the interactions of the G2-S16 dendrimer either with A549 cellular entry receptors or with viral proteins.

To test the first hypothesis, A549 cells were incubated 30 min with G2-S16 dendrimer and we washed the unbound G2-S16 dendrimer prior to RSV infection, resulting in a significant RSV inhibition of 83-84\% $(p<0.01)$ (Figure 2C). The next step was to test the other interaction of the G2-S16 dendrimer with the RSV virions hypothesis. In this case, not significant inhibition was observed when the G2-S16 dendrimer was incubated with RSV particles prior to infecting A549 cells (11-12\%) (Figure 2D). These results are in line with our previous experiments, demonstrating that the inhibitory action of G2-S16 dendrimer was due to an interaction with host cell receptors.

\subsection{Inhibition of Syncytium Formation}

Syncytium formation is a well-known mechanism of cell-to-cell infection that contributes significantly to virus spread in vivo. The RSV specifically uses syncytium formation to spread infection. To determine whether G2-S16 dendrimer prevents cell-to-cell spread of RSV after infection, a syncytium formation assay was performed on infected A549 cells after $72 \mathrm{~h}$. The G2-S16 dendrimer was not toxic at the range of concentrations evaluated on A549 cells (Figure 1D). The inhibition range of the G2-S16 dendrimer was also measured in A549 cells at a MOI 3 (Figure $3 \mathrm{~A}$ ) to determine $\mathrm{EC}_{50}$ and subsequently, therapeutic index (SI).
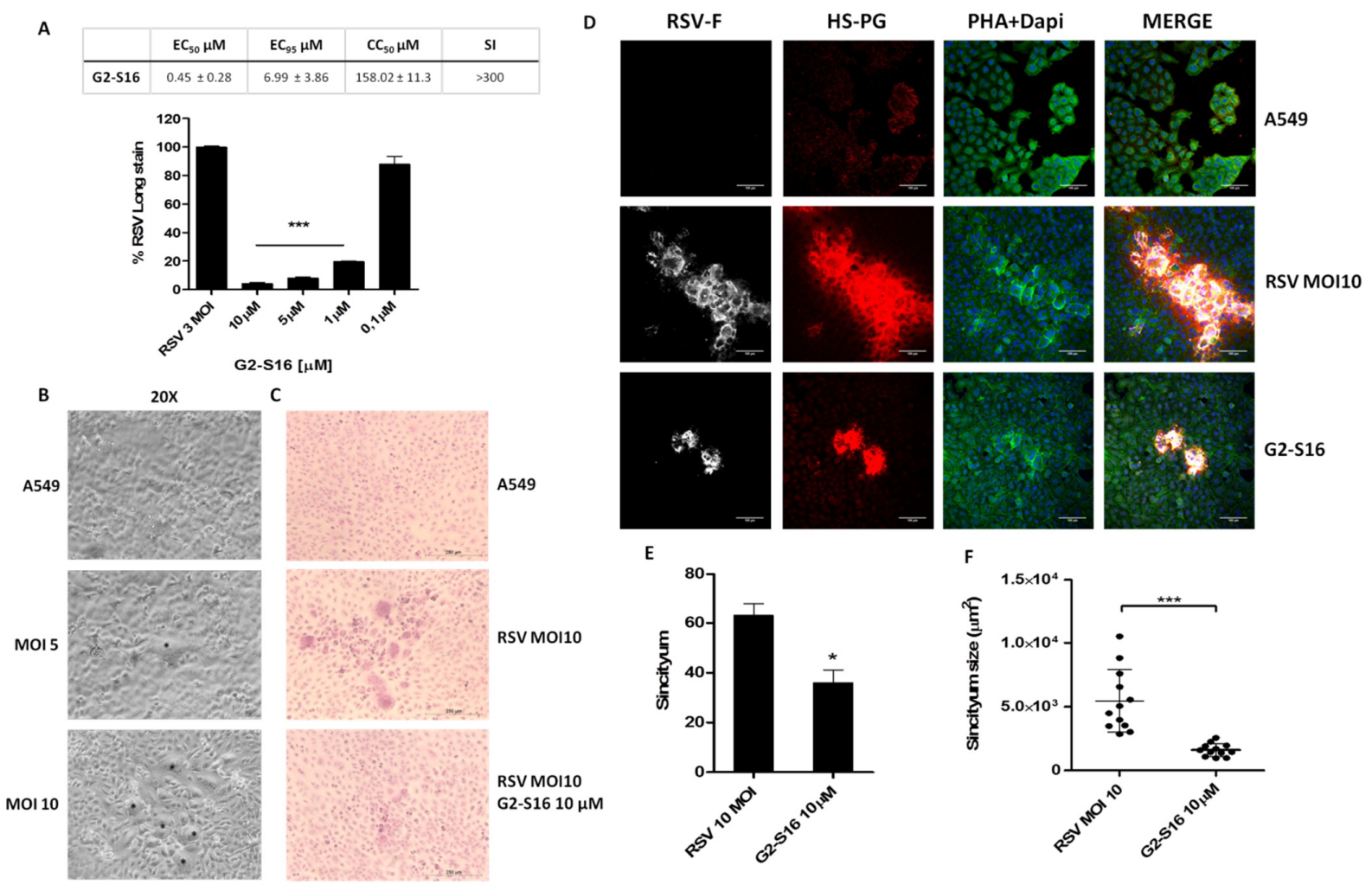
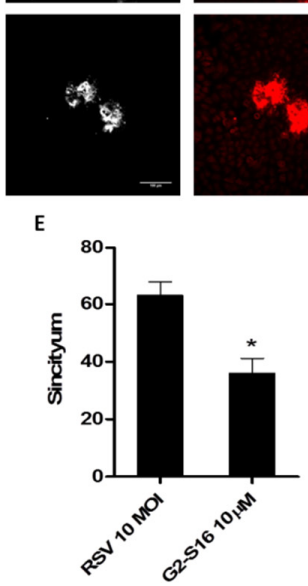
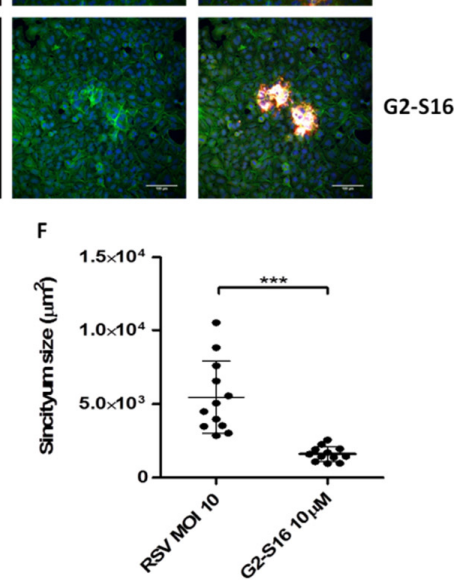

Figure 3. Syncytium formation assay. (A) A549 cells were infected at a MOI 3 to evaluate the inhibition of G2-S16 dendrimer. EC50, EC95, CC50, and SI were calculated. (B) A549 cells were infected at different MOI of RSV to evaluate the syncytium formation (black asterisk). A549 cells were infected at a MOI 10 (C-F) of RSV and treated with G2-S16 dendrimer in a range of non-toxic concentrations. Then, $72 \mathrm{~h}$ post-infection, cells were (C) H/E stained or immune-stained for (D) RSV-F viral glycoprotein (white), HSPG (red), and actin filaments (phalloidin; green). Nuclei were stained with DAPI (blue). (E) Media of syncytium formation/well after $72 \mathrm{~h}$ post-infection. (F) Media of syncytium size in four random fields/experiment after $72 \mathrm{~h}$ post-infection analyzed with ImageJ software. Images are representative of three independent experiments. Data showed the media $\pm \mathrm{SD}$ of three independent experiments. ${ }^{*}: p<0.05 ; * *: p<0.001$. 
Firstly, A549 cells were infected with RSV at a different MOI to allow syncytium formation and visualization. MOI 10 was selected for syncytium assays (Figure 3B). A549 cells were infected with RSV, treated with G2-S16 dendrimer, and stained for H/E (Figure 3C). Even the increase in RSV quantity, the G2-S16 dendrimer was able to reduce the number and mainly the size of the syncytium generated (Figure 3E,F). Infected A549 cells were also immune-stained to confirm inhibition observed in optical microscopy (Figure 3D). A549 cells were fixed $72 \mathrm{~h}$ post-infection and stained for RSV-F viral protein (white), HSPG (red), phalloidin (green), and nuclei with DAPI (Figure 3D). Our data demonstrated that treatment with G2-S16 dendrimer, even RSV infection, when performed at a MOI 10 reduced significantly the syncytium quantity and mainly the size of the formed multinuclear cells. Interestingly, when RSV infection occurs and syncytium is formed, the images reveal a polarization in the main receptor of RSV, HSPG, favoring infection and co-locating with RSV-F. We demonstrated that the G2-S16 dendrimer reduces syncytium formation, particularly the size of the syncytium, indicating a promising function against RSV infection. Thus, the next step was to locate the G2-S16 dendrimer in syncytium formation.

The G2-S16-FITC labeled dendrimer was used to determine the position of the G2-S16 dendrimer in syncytium generation. A549 cells were infected at MOI 10 of RSV as mentioned above and treated with a mix of non-toxic concentrations (Figure 1) of G2-S16 dendrimer $(5 \mu \mathrm{M})$ and G2-S16-FITC $(5 \mu \mathrm{M})$ to observe visualization of the dendrimers. Then, $72 \mathrm{~h}$ post-infection, A549 cells were immune-stained for RSV-F glycoprotein and HSPG. G2-S16-FITC was observed in green (Figure 4). DAPI was used for nuclei visualization.

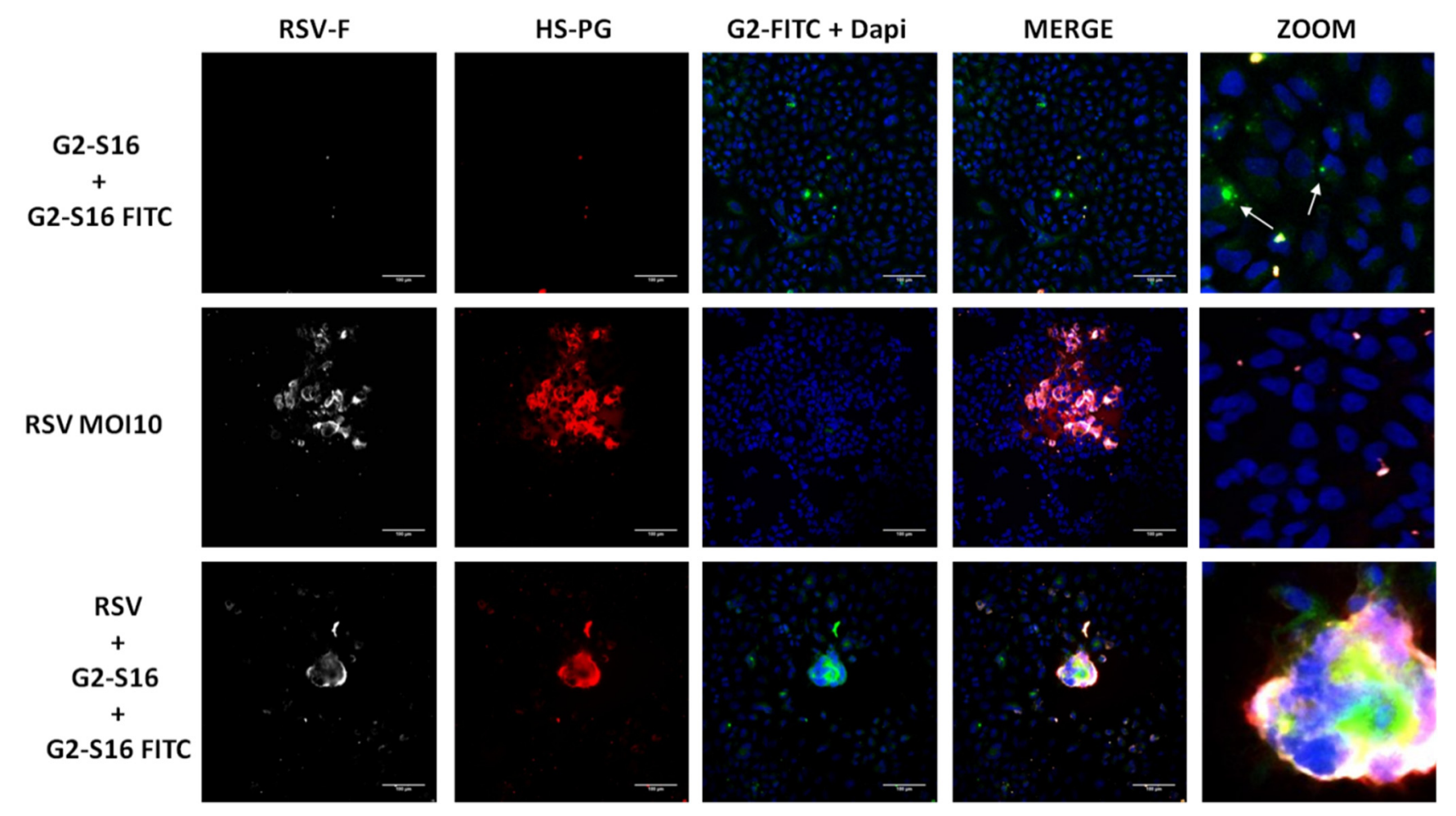

Figure 4. Presence of G2-S16 dendrimer in syncytium formation. A549 cells were infected with RSV at MOI 10 and treated with a mix of G2-S16 $(5 \mu \mathrm{M})$ and G2-S16 FITC $(5 \mu \mathrm{M})$ dendrimers. Then, $72 \mathrm{~h}$ post-infection, A549 cells were fixed and immune-stained for RSV-F glycoprotein (white), HSPG (red), and DAPI nuclei visualization (blue). Images are representative of three independent experiments.

As expected, in fields without the presence of RSV, the G2-S16 dendrimer is located inside A549 cells, mainly at the cellular surface (Figure 4; white arrows). These data are in concordance with cellular protection assay results, where the G2-S16 dendrimer is able to interact with A549 cells and protect RSV infection. In these fields where syncytium was 
generated, the G2-S16-FITC dendrimer was visualized inside the syncytium (Figure 4), suggesting that it could interfere with adjacent cells, avoiding syncytium spread.

3.5. In Vivo Experiments: Murine Lung Model for Viability of G2-S16 Dendrimer and Respiratory Syncytial Virus Challenge

Once it was demonstrated that G2-S16 dendrimer inhibits RSV and the underlying mechanism of action by which the inhibition occurs, we studied if G2-S16 dendrimer induces irritation and/or damage in mice lungs when this G2-S16 dendrimer was administrated intranasally in BALB/c mice. No damage or alteration to the lung epithelium was shown when the G2-S16 dendrimer was applied intranasally at concentrations up to $46.5 \mathrm{mg} / \mathrm{kg}$ in mice lung. However, the G2-S16 dendrimer showed slight toxicity in lungs (inflammation, vascular thrombosis, and congestion and atelectasis) at high concentrations of $93 \mathrm{mg} / \mathrm{kg}$. However, those data suggest that the application method could be the reason for the G2-S16 dendrimer toxicity in vivo (Table 1).

Table 1. Lung and pleura toxicity assay. The existence of injury in pulmonary parenchyma (inflammation, edema, alveolar congestion, bleeding, and vascular thrombosis or congestion) was evaluated in each biological sample.

\begin{tabular}{|c|c|c|c|c|c|c|c|c|c|c|c|c|}
\hline \multirow{2}{*}{$\begin{array}{c}\text { Pulmonary Parenchyma } \\
\text { Inflammation }\end{array}$} & \multicolumn{3}{|c|}{ PBS } & \multicolumn{3}{|c|}{$9.3 \mathrm{mg} / \mathrm{kg}$} & \multicolumn{3}{|c|}{$46.5 \mathrm{mg} / \mathrm{kg}$} & \multicolumn{3}{|c|}{$93 \mathrm{mg} / \mathrm{kg}$} \\
\hline & $0^{1}$ & 1 & 3 & 2 & 2 & 2 & 2 & 1 & 3 & 2 & 2 & 1 \\
\hline Edema & 0 & 0 & 0 & 0 & 0 & 0 & 0 & 0 & 0 & 0 & 0 & 0 \\
\hline Alveolar congestion & 0 & 0 & 3 & 1 & 1 & 2 & 1 & & 2 & 3 & 2 & 1 \\
\hline Bleeding & 1 & 0 & 1 & 1 & 0 & 1 & 0 & 0 & 0 & 0 & 0 & 0 \\
\hline $\begin{array}{c}\text { Vascular thrombosis or } \\
\text { congestion }\end{array}$ & 1 & 1 & 1 & 0 & 1 & 1 & 1 & 2 & 1 & 2 & 3 & 2 \\
\hline Atelectasis & 1 & 1 & 3 & 2 & 2 & 2 & 2 & 1 & 3 & 3 & 2 & 1 \\
\hline Emphysema & 0 & 0 & 0 & 0 & 0 & 0 & 0 & 0 & 0 & 0 & 0 & 0 \\
\hline Pleura & \multicolumn{3}{|c|}{ PBS } & \multicolumn{3}{|c|}{$9.3 \mathrm{mg} / \mathrm{kg}$} & \multicolumn{3}{|c|}{$46.5 \mathrm{mg} / \mathrm{kg}$} & \multicolumn{3}{|c|}{$93 \mathrm{mg} / \mathrm{kg}$} \\
\hline Inflammatory infiltrate & 0 & 0 & 0 & 0 & 0 & 0 & 0 & 0 & 0 & 0 & 0 & 0 \\
\hline Edema & 0 & 0 & 0 & 0 & 0 & 0 & 0 & 0 & 0 & 0 & 0 & 0 \\
\hline Bleeding & 0 & 0 & 0 & 0 & 0 & 0 & 0 & 0 & 0 & 0 & 0 & 0 \\
\hline Neovasculation & 0 & 0 & 0 & 0 & 0 & 0 & 0 & 0 & 0 & 0 & 0 & 0 \\
\hline
\end{tabular}

${ }^{1} 0$ (no change); 1 (minimum); 2 (light); 3 (moderate); 4 (very serious). These values were added up to determine the level of vaginal irritation as minimum $1-6$, average $7-10$, moderate $10-14$, and severe $14+$.

Histological analysis of mice lung clearly reveals the minimum or average damage in all analyzed lungs. This is probably due to the application method, because PBS, which is non-toxic control, also reveals average damage in all analyzed samples.

Due to the data obtained in an accumulated score, the presence of pulmonary injuries in treatment with PBS showed that scores observed in G2-S16 dendrimer treatment are not significantly related to PBS biocompatibility control, suggesting that the G2-S16 dendrimer is safe for further in vivo assays (Figure 5). It is also important to note that no damage was detected in pleura analysis in any of mice analyzed samples. Mice samples treated with G2-S16 dendrimer present mainly an alveolar congestion and a moderate infiltrate, being more serious in samples treated with $1 \mathrm{mM}$ of G2-S16 dendrimer and minimum in those $\mathrm{BALB} / \mathrm{c}$ mice treated with $9.3 \mathrm{mg} / \mathrm{Kg}$ of G2-S16 dendrimer. Based on the data obtained, the concentration of $93 \mathrm{mg} / \mathrm{Kg}$ is the best one as well as the concentration selected for RSV in vivo challenge. 
a
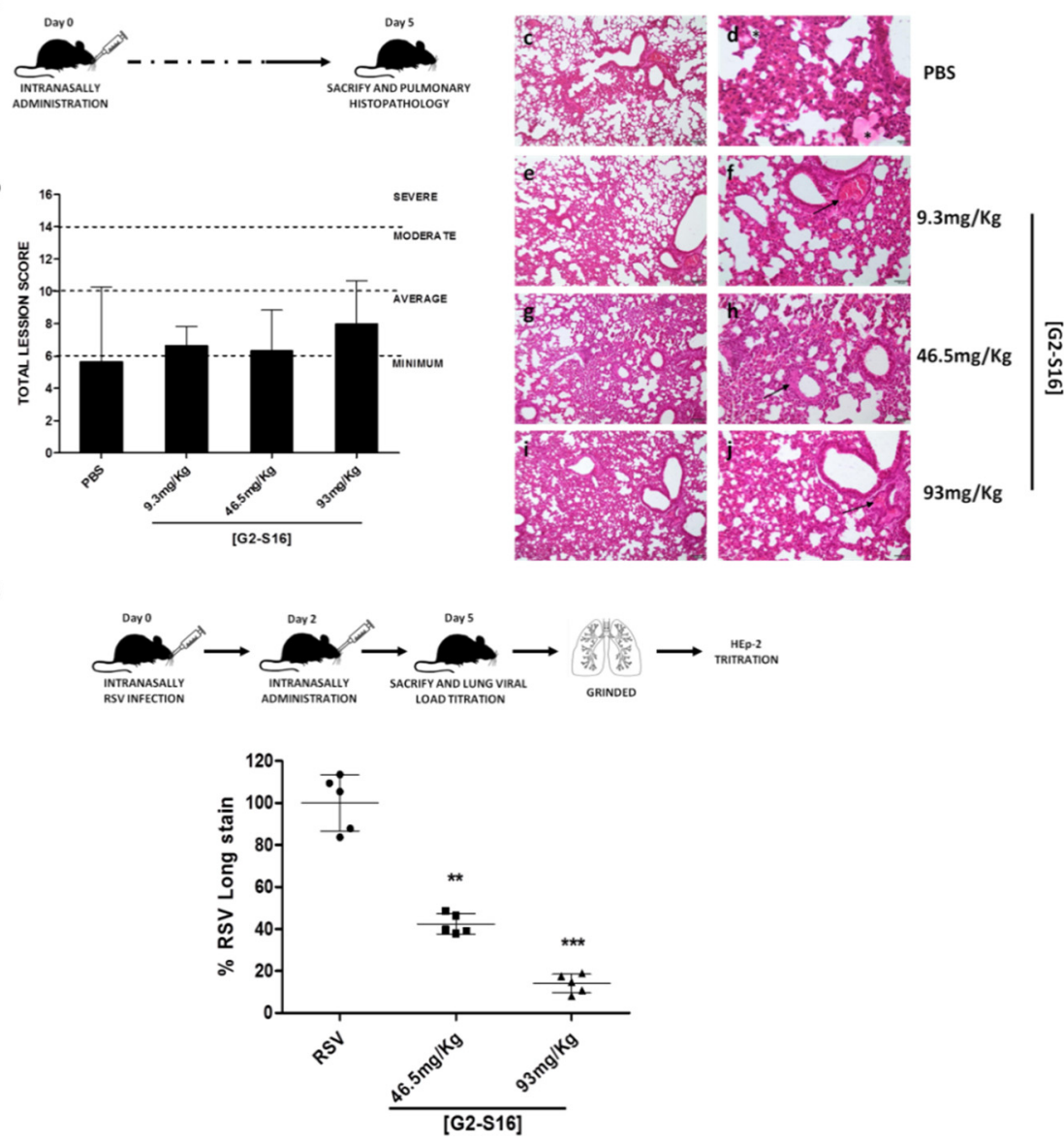

Figure 5. In vivo experiments with G2-S16 dendrimer. (a) Schematic representation of in vivo viability procedure. (b) Media of the accumulate score for each treatment group. (c-j) Histological studies of pulmonary damage. (b-d) Focal and minimal inflammatory infiltrate and atelectasis around the presence of an acellular and eosinophilic substance (possibly PBS) (asterisk). (e,f) Alveolar congestion of medium severity mainly around bronchioles and vessels in both cases (arrows). (g,h) Thickening of the walls of the arterioles in the areas of inflammation (arrows). (i,j) More diffuse lesions in the lung parenchyma with congestion and alveolar atelectasis. Presence of thrombi in vessels (arrow). (k) Schematic representation of in vivo antiviral activity procedure. (1) Percentages of inhibition of G2-S16 dendrimer corresponding to RSV infection of BALB/c mice and subsequent titer of the lung infection HEp-2 cells for 5 days. The figure represents the relative mean of five mice per group. RSV: BALB/c mice RSV infected and treated with PBS. ${ }^{* *}: p<0.01 ;{ }^{* * *}: p<0.001$.

Finally, we also studied the antiviral activity of the G2-S16 dendrimer against RSV challenge in BALB/C mice. Intranasal administration of the G2-S16 dendrimer reduced RSV replication and infection in a significant manner. The administration of $50 \mu \mathrm{L}$ of G2-S16 dendrimer $93 \mathrm{mg} / \mathrm{Kg}$, after $4 \mathrm{~h}$ post-exposure to a high dose of RSV, abrogated RSV infection in $86 \%$ ( $p<0.0001$ vs. placebo) (Figure 5). Interestingly and importantly, the G2-S16 dendrimer at $46.5 \mathrm{mg} / \mathrm{Kg}$ inhibited RSV infection in $56 \%$ of BALB/C mice.

\section{Discussion}

RSV is the main cause of respiratory mortality and morbidity in persons of all ages [28-30]. Particularly, RSV is the main cause of acute lower respiratory tract infections in children less than 5 years of age and responsible for substantial disease burden in the elderly. The G2-S16 dendrimer presents different types of functionalized groups at their periphery, including antiviral activities [31,32]. The biodistribution and biocompatibility of the G2-S16 dendrimer have now been evaluated after administration at a systemic level, and resistant mutation appearance was evaluated in HIV-1 infection [33]. 
Herein, we demonstrate that the G2-S16 dendrimer inhibits RSV infection not only in an in vitro cellular model but also in a BALB/c mice in vivo model. Evaluation of the cytotoxicity of the G2-S16 dendrimer has shown that this dendrimer is non-toxic in A549 cells at selected concentrations and that this G2-S16 dendrimer is capable of significantly inhibiting RSV infection in the A549 cell line (>99\%) (Figure 2). Studies of cytotoxicity and inhibition curves made it possible to calculate the selectivity index (SI) of the G2-S16 dendrimer, enabling a value of $>300$ for RSV inhibition. Based on these previous results, the mechanism of action by which the G2-S16 dendrimer inhibits RSV and the interaction with A549 cells was studied.

Firstly, data obtained in attachment assay demonstrated that the inhibition by G2-S16 dendrimer (99-100\%) (Figure 2) was due to the ability of the G2-S16 dendrimer to destabilize or prevent the interactions of the RSV virions with the cell host receptors. This first step confirms that G2-S16 dendrimer inhibition occurs in the entry early events of RSV infection. Data also confirm that this inhibition is mediated by an interaction of G2-S16 dendrimer with cellular receptors (Figure 2); meanwhile, the interaction of the G2-S16 dendrimer with the RSV viral particles does not generate a significant effect in the RSV infection (Figure 2). All these data demonstrate that the G2-S16 dendrimer is capable of interacting with host cellular receptors implied in the RSV infection. We previously described that G2-S16 dendrimer interacts with cellular HS and HBD in HSV infection [34-37]. We also previously described that the G2-S16 dendrimer could interact electrostatically with the viral glycoproteins of the viral surface as well as cellular receptors [21,22]. Interestingly, the RSV cellular entry mediators in the viral infection are mainly the HSPG, in such a way that it allows us to hypothesize that the RSV inhibition demonstrated by the G2-S16 dendrimer could be due to the interaction of the dendrimer with HSPG of the cellular surface, blocking this crucial initial step of the RSV infection.

In addition to the mechanism of action, we described the ability of the G2-S16 dendrimer to halt RSV infection in vitro related to the syncytium formation and size in pulmonary A549 cells (Figure 3). Our data suggest that the G2-S16 dendrimer halts syncytium formation targeting cellular receptors, which are data that are in concordance with the results obtained in mechanism of action assays.

Due to the potential use of the G2-S16 dendrimer as a possible treatment against RSV in vivo, we studied its biocompatibility in BALB/C mice. Our results clearly showed that the G2-S16 dendrimer applied intranasally at $93 \mathrm{mg} / \mathrm{kg}$ in BALB/c mice was well tolerated, and no significant signs or damage to pulmonary parenchyma or pleura were observed (Table 1). In addition, we also analyzed the antiviral activity of the G2-S16 dendrimer in BALB/c mice, and we demonstrated that it decreased by $86 \%$ when RSV infected BALB/c mice were treated with this G2-S16 dendrimer (Figure 5).

\section{Conclusions}

The G2-S16 dendrimer was demonstrated to be an effective treatment against RSV infection. G2-S16 inhibits RSV infection in vitro and in vivo, and it presents good biocompatibility in vivo. In conclusion, G2-S16 dendrimer therapeutic application needs careful design and treatment regimen to be considered effective for RSV treatment. G2-S16 dendrimer in combination with biocompatible drugs and/or molecules could be a promising therapeutic for that infection. The use of G2-S16 dendrimer could also contribute to finding a solution to prevent RSV infection in infants and other target populations.

Author Contributions: Conceptualization, R.R.-F., I.M. and M.M.-F.; Data curation, I.R.-I., R.C.-D. and M.J.S.; Formal analysis, R.R.-F. and I.M.; Funding acquisition, M.M.-F.; Investigation, I.R.-I. and R.C.-D.; Methodology, I.R.-I., R.C.-D. and M.J.S.; Software, I.R.-I. and R.C.-D.; Supervision, M.M.-F.; Validation, R.R.-F., I.M. and M.M.-F.; Writing-original draft, I.R.-I., R.C.-D. and R.R.-F.; Writing-review \& editing, I.M. and M.M.-F. All authors have read and agreed to the published version of the manuscript.

Funding: This work has been (partially) funded by the RD16/0025/0019, projects as part of Acción Estratégica en Salud, Plan Nacional de Investigación Científica, Desarrollo e Innovación Tecnológica 
(2013-2016) and co-financed by Instituto de Salud Carlos III (Subdirección General de Evaluación) and Fondo Europeo de Desarrollo Regional (FEDER), RETIC PT17/0015/0042, Fondo de Investigacion Sanitaria (FIS) (grant number PI19/01638) and EPIICAL project. CIBER-BBN is an initiative funded by the VI National R\&D\&i Plan 2008-2011, Iniciativa Ingenio 2010, the Consolider Program, and CIBER Actions and financed by the Instituto de Salud Carlos III with assistance from the European Regional Development Fund. This work has been supported partially by the EUROPARTNER: Strengthening and spreading international partnership activities of the Faculty of Biology and Environmental Protection for interdisciplinary research and innovation of the University of Lodz Programme: NAWA International Academic Partnership Programme. This article/publication is based upon work from COST Action CA 17140 "Cancer Nanomedicine from the Bench to the Bedside" supported by COST (European Cooperation in Science and Technology).

Institutional Review Board Statement: The study was conducted according to the guidelines of the Declaration of Helsinki. Animal studies were approved by Ethic Experimental Animals Committee of the Centro de Biología Molecular "Severo Ochoa" (EEACCBMSO Institutional Animal Care and Use Committee (EEAC-CBMSO, Madrid, Spain)). (PROES 136/14; Register number ES-280790000180). All experiments were carried out following EECA-CBMSO, National (Royal Decree 1201/2005) and the Directive 2010/63/EU of the European Parliament guidelines and regulations.

Informed Consent Statement: Not applicable.

Conflicts of Interest: The authors declare no conflict of interest. The funders had no role in the design of the study; in the collection, analyses, or interpretation of data; in the writing of the manuscript, or in the decision to publish the results.

\section{References}

1. Valdez, J.; Bawage, S.; Gomez, I.; Singh, S.R. Facile and rapid detection of respiratory syncytial virus using metallic nanoparticles. J. Nanobiotechnol. 2016, 14, 13. [CrossRef]

2. Mazur, N.I.; Higgins, D.; Nunes, M.C.; Melero, J.A.; Langedijk, A.C.; Horsley, N.; Buchholz, U.J.; Openshaw, P.J.; McLellan, J.S.; Englund, J.A.; et al. The respiratory syncytial virus vaccine landscape: Lessons from the graveyard and promising candidates. Lancet Infect. Dis. 2018, 18, e295-e311. [CrossRef]

3. Mejias, A.; Rodriguez-Fernandez, R.; Peeples, M.E.; Ramilo, O. Respiratory syncytial virus vaccines: Are we making progress? Pediatr. Infect. Dis. J. 2019, 38, e266-e269. [CrossRef]

4. Mejias, A.; Rodriguez-Fernandez, R.; Oliva, S.; Peeples, M.E.; Ramilo, O. The journey to a respiratory syncytial virus vaccine. Ann. Allergy Asthma Immunol. 2020, 125, 36-46. [CrossRef]

5. Santos, L.D.; Antunes, K.H.; Muraro, S.P.; de Souza, G.F.; da Silva, A.G.; de Souza Felipe, J.; Zanetti, L.C.; Czepielewski, R.S.; Magnus, K.; Scotta, M.; et al. Tnf-mediated alveolar macrophage necroptosis drives disease pathogenesis during respiratory syncytial virus infection. Eur. Respir. J. 2020, 57, 2003764. [CrossRef] [PubMed]

6. Papadopoulos, N.G.; Megremis, S.; Kitsioulis, N.A.; Vangelatou, O.; West, P.; Xepapadaki, P. Promising approaches for the treatment and prevention of viral respiratory illnesses. J. Allergy Clin. Immunol. 2017, 140, 921-932. [CrossRef] [PubMed]

7. Rodriguez-Izquierdo, I.; Seramia, M.J.; Gomez, R.; de la Mata, F.J.; Bullido, M.J.; Munoz-Fernandez, M.A. Gold nanoparticles crossing blood-brain barrier prevent hsv-1 infection and reduce herpes associated amyloid-betasecretion. J. Clin. Med. 2020, 9, 155.

8. Pissuwan, D.; Niidome, T. Polyelectrolyte-coated gold nanorods and their biomedical applications. Nanoscale 2015, 7, 59-65. [CrossRef]

9. Bawage, S.S.; Tiwari, P.M.; Singh, A.; Dixit, S.; Pillai, S.R.; Dennis, V.A.; Singh, S.R. Gold nanorods inhibit respiratory syncytial virus by stimulating the innate immune response. Nanomedicine 2016, 12, 2299-2310. [CrossRef]

10. Markoutsa, E.; McGill, A.R.; Singer, A.; Jadhav, H.; Mohapatra, S.; Mohapatra, S.S. A multifunctional nanoparticle as a prophylactic and therapeutic approach targeting respiratory syncytial virus. Nanomed. Nanotechnol. Biol. Med. 2020, 32, 102325. [CrossRef]

11. Nikonova, A.; Shilovskiy, I.; Galitskaya, M.; Sokolova, A.; Sundukova, M.; Dmitrieva-Posocco, O.; Mitin, A.; Komogorova, V.; Litvina, M.; Sharova, N.; et al. Respiratory syncytial virus upregulates il-33 expression in mouse model of virus-induced inflammation exacerbation in ova-sensitized mice and in asthmatic subjects. Cytokine 2020, 138, 155349. [CrossRef]

12. Kellar, G.G.; Barrow, K.A.; Rich, L.M.; Debley, J.S.; Wight, T.N.; Ziegler, S.F.; Reeves, S.R. Loss of versican and production of hyaluronan in lung epithelial cells are associated with airway inflammation during rsv infection. J. Biol. Chem. 2020, $296,100076$. [CrossRef]

13. Bourgeois, C.; Bour, J.B.; Lidholt, K.; Gauthray, C.; Pothier, P. Heparin-like structures on respiratory syncytial virus are involved in its infectivity in vitro. J. Virol. 1998, 72, 7221-7227. [CrossRef] [PubMed]

14. Escribano-Romero, E.; Rawling, J.; Garcia-Barreno, B.; Melero, J.A. The soluble form of human respiratory syncytial virus attachment protein differs from the membrane-bound form in its oligomeric state but is still capable of binding to cell surface proteoglycans. J. Virol. 2004, 78, 3524-3532. [CrossRef] 
15. Feldman, S.A.; Audet, S.; Beeler, J.A. The fusion glycoprotein of human respiratory syncytial virus facilitates virus attachment and infectivity via an interaction with cellular heparan sulfate. J. Virol. 2000, 74, 6442-6447. [CrossRef]

16. Feldman, S.A.; Hendry, R.M.; Beeler, J.A. Identification of a linear heparin binding domain for human respiratory syncytial virus attachment glycoprotein g. J. Virol. 1999, 73, 6610-6617. [CrossRef]

17. Harris, J.; Werling, D. Binding and entry of respiratory syncytial virus into host cells and initiation of the innate immune response. Cell. Microbiol. 2003, 5, 671-680. [CrossRef]

18. Karger, A.; Schmidt, U.; Buchholz, U.J. Recombinant bovine respiratory syncytial virus with deletions of the $g$ or sh genes: $\mathrm{G}$ and f proteins bind heparin. J. Gen. Virol. 2001, 82, 631-640. [CrossRef]

19. Krusat, T.; Streckert, H.J. Heparin-dependent attachment of respiratory syncytial virus (rsv) to host cells. Arch. Virol. 1997, 142, 1247-1254. [CrossRef]

20. Martinez, I.; Melero, J.A. Binding of human respiratory syncytial virus to cells: Implication of sulfated cell surface proteoglycans. J. Gen. Virol. 2000, 81, 2715-2722. [CrossRef]

21. Arnaiz, E.; Doucede, L.I.; Garcia-Gallego, S.; Urbiola, K.; Gomez, R.; Tros de Ilarduya, C.; de la Mata, F.J. Synthesis of cationic carbosilane dendrimers via click chemistry and their use as effective carriers for DNA transfection into cancerous cells. Mol. Pharm. 2012, 9, 433-447. [CrossRef]

22. Galan, M.; Sanchez Rodriguez, J.; Jimenez, J.L.; Relloso, M.; Maly, M.; de la Mata, F.J.; Munoz-Fernandez, M.A.; Gomez, R. Synthesis of new anionic carbosilane dendrimers via thiol-ene chemistry and their antiviral behaviour. Org. Biomol. Chem. 2014, 12, 3222-3237. [CrossRef]

23. Rasines, B.; Sanchez-Nieves, J.; Maiolo, M.; Maly, M.; Chonco, L.; Jimenez, J.L.; Munoz-Fernandez, M.A.; de la Mata, F.J.; Gomez, R. Synthesis, structure and molecular modelling of anionic carbosilane dendrimers. Dalton Trans. 2012, 41, 12733-12748. [CrossRef]

24. Martinez, I.; Dopazo, J.; Melero, J.A. Antigenic structure of the human respiratory syncytial virus g glycoprotein and relevance of hypermutation events for the generation of antigenic variants. J. Gen. Virol. 1997, 78 Pt 10, 2419-2429. [CrossRef]

25. Mbiguino, A.; Menezes, J. Purification of human respiratory syncytial virus: Superiority of sucrose gradient over percoll, renografin, and metrizamide gradients. J. Virol. Methods 1991, 31, 161-170. [CrossRef]

26. Guerrero-Beltran, C.; Rodriguez-Izquierdo, I.; Serramia, M.J.; Araya-Duran, I.; Marquez-Miranda, V.; Gomez, R.; de la Mata, F.J.; Leal, M.; Gonzalez-Nilo, F.; Munoz-Fernandez, M.A. Anionic carbosilane dendrimers destabilize the gp120-cd4 complex blocking hiv-1 entry and cell to cell fusion. Bioconjug. Chem. 2018, 29, 1584-1594. [CrossRef] [PubMed]

27. Rusnati, M.; Vicenzi, E.; Donalisio, M.; Oreste, P.; Landolfo, S.; Lembo, D. Sulfated k5 escherichia coli polysaccharide derivatives: A novel class of candidate antiviral microbicides. Pharm. Ther. 2009, 123, 310-322. [CrossRef] [PubMed]

28. Thomas, E.; Mattila, J.M.; Lehtinen, P.; Vuorinen, T.; Waris, M.; Heikkinen, T. Burden of respiratory syncytial virus infection during the first year of life. J. Infect. Dis. 2020, 223, 811-817. [CrossRef]

29. Pena, M.; Jara, C.; Flores, J.C.; Hoyos-Bachiloglu, R.; Iturriaga, C.; Medina, M.; Carcey, J.; Espinoza, J.; Bohmwald, K.; Kalergis, A.M.; et al. Severe respiratory disease caused by human respiratory syncytial virus impairs language learning during early infancy. Sci. Rep. 2020, 10, 22356. [CrossRef]

30. Behzadi, M.A.; Leyva-Grado, V.H. Overview of current therapeutics and novel candidates against influenza, respiratory syncytial virus, and middle east respiratory syndrome coronavirus infections. Front. Microbiol. 2019, 10, 1327. [CrossRef]

31. Dzmitruk, V.; Szulc, A.; Shcharbin, D.; Janaszewska, A.; Shcharbina, N.; Lazniewska, J.; Novopashina, D.; Buyanova, M.; Ionov, M.; Klajnert-Maculewicz, B.; et al. Anticancer sirna cocktails as a novel tool to treat cancer cells. Part (b). Efficiency of pharmacological action. Int. J. Pharm. 2015, 485, 288-294. [CrossRef]

32. Perise-Barrios, A.J.; Gomez, R.; Corbi, A.L.; de la Mata, J.; Dominguez-Soto, A.; Munoz-Fernandez, M.A. Use of carbosilane dendrimer to switch macrophage polarization for the acquisition of antitumor functions. Nanoscale 2015, 7, 3857-3866. [CrossRef] [PubMed]

33. Rodriguez-Izquierdo, I.; Natalia, C.; Garcia, F.; los Ángeles Munoz-Fernandez, M. G2-s16 sulfonate dendrimer as new therapy for treatment failure in hiv-1 entry inhibitors. Nanomedicine 2019, 14, 1095-1107. [CrossRef] [PubMed]

34. Cena-Diez, R.; Vacas-Cordoba, E.; Garcia-Broncano, P.; de la Mata, F.J.; Gomez, R.; Maly, M.; Munoz-Fernandez, M.A. Prevention of vaginal and rectal herpes simplex virus type 2 transmission in mice: Mechanism of antiviral action. Int J. Nanomed. 2016, 11, 2147-2162.

35. Sepulveda-Crespo, D.; Sanchez-Rodriguez, J.; Serramia, M.J.; Gomez, R.; De La Mata, F.J.; Jimenez, J.L.; Munoz-Fernandez, M.A. Triple combination of carbosilane dendrimers, tenofovir and maraviroc as potential microbicide to prevent hiv-1 sexual transmission. Nanomedicine 2015, 10, 899-914. [CrossRef] [PubMed]

36. Rodriguez-Izquierdo, I.; Gasco, S.; Munoz-Fernandez, M.A. High preventive effect of g2-s16 anionic carbosilane dendrimer against sexually transmitted hsv-2 infection. Molecules 2020, 25, 2965. [CrossRef] [PubMed]

37. Guerrero-Beltran, C.; Garcia-Heredia, I.; Cena-Diez, R.; Rodriguez-Izquierdo, I.; Serramia, M.J.; Martinez-Hernandez, F.; LluesmaGomez, M.; Martinez-Garcia, M.; Munoz-Fernandez, M.A. Cationic dendrimer g2-s16 inhibits herpes simplex type 2 infection and protects mice vaginal microbiome. Pharmaceutics 2020, 12, 515. [CrossRef] 